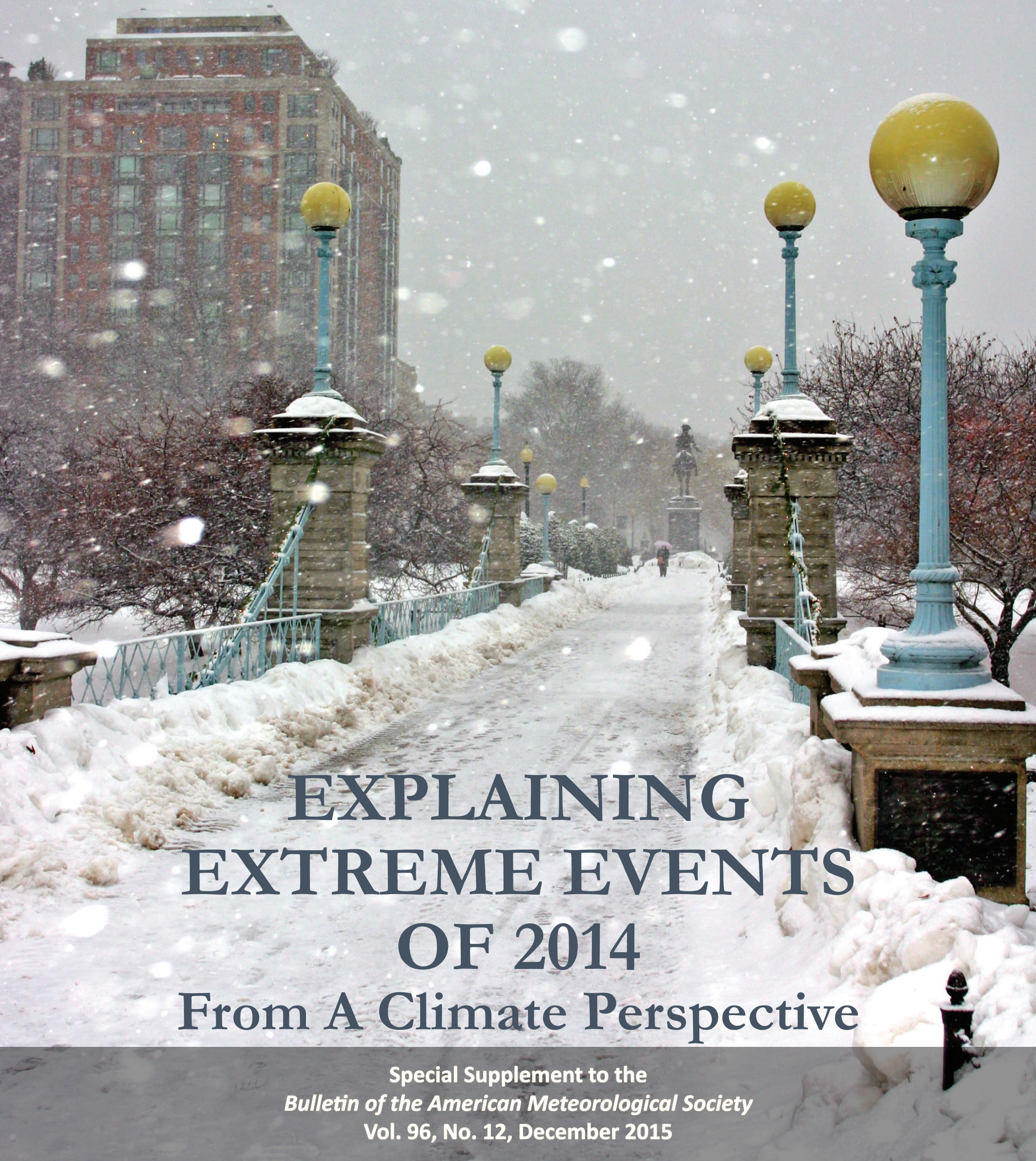




\section{EXPLAINING EXTREME EVENTS OF 20I4 FROM A CLIMATE PERSPECTIVE}

\section{Editors}

Stephanie C. Herring, Martin P. Hoerling, James P. Kossin, Thomas C. Peterson, and Peter A. Stott

Special Supplement to the

Bulletin of the American Meteorological Society

Vol. 96, No. I2, December 2015 
CORRESPONDING EDITOR:

Stephanie C. Herring, PhD

NOAA National Centers for Environmental Information

325 Broadway, E/CC23, Rm IB-I3I

Boulder, CO 80305-3328

E-mail: stephanie.herring@noaa.gov

COVER CREDITS:

FRONT: (CiStockphotos.com/coleong-Winter snow, Boston, Massachusetts, United States.

BACK: (iStockphotos.com/nathanphoto-Legget, California, United States - August 13, 20I4: CAL FIRE helicopter surveys a part of the Lodge Fire, Mendocino County.

\section{HOW TO CITE THIS DOCUMENT}

Citing the complete report:

Herring, S. C., M. P. Hoerling, J. P. Kossin, T. C. Peterson, and P. A. Stott, Eds., 20I5: Explaining Extreme Events of 2014 from a Climate Perspective. Bull. Amer. Meteor. Soc., 96 (I2), SI-SI72.

Citing a section (example):

Yoon, J. H., S.-Y. S. Wang, R. R. Gillies, L. Hipps, B. Kravitz, and P. J. Rasch, 20I5: Extreme fire season in California: A glimpse into the future? [in "Explaining Extremes of 20I4 from a Climate Perspective”]. Bull. Amer. Meteor. Soc., 96 (I2), S5-S9.

\section{EDITORIAL AND PRODUCTION TEAM}

Riddle, Deborah B., Lead Graphics Production, NOAA/NESDIS National Centers for Environmental Information,

Asheville, NC

Love-Brotak, S. Elizabeth, Graphics Support, NOAA/NESDIS National Centers for Environmental Information,

Asheville, NC

Veasey, Sara W., Visual Communications Team Lead, NOAA/ NESDIS National Centers for Environmental Information, Asheville, NC

Griffin, Jessicca, Graphics Support, Cooperative Institute for Climate and Satellites-NC, North Carolina State University, Asheville, NC

Maycock, Tom, Editorial Support, Cooperative Institute for Climate and Satellites-NC, North Carolina State University, Asheville, NC
Misch, Deborah J., Graphics Support, LMI Consulting, Inc., NOAA/NESDIS National Centers for Environmental Information, Asheville, NC

Osborne, Susan, Editorial Support, LMI Consulting, Inc., NOAA/NESDIS National Centers for Environmental Information, Asheville, NC

Schreck, Carl, Editorial Support, Cooperative Institute for Climate and Satellites-NC, North Carolina State University, and NOAA/NESDIS National Centers for Environmental Information, Asheville, NC

Sprain, Mara, Editorial Support, LAC Group, NOAA/NESDIS National Centers for Environmental Information, Asheville, NC

Young, Teresa, Graphics Support, STG, Inc., NOAA/NESDIS National Centers for Environmental Information, Asheville, NC 
Abstract.

I. Introduction to Explaining Extreme Events of 2014 from a Climate Perspective .................................

2. Extreme Fire Season in California: A Glimpse Into the Future? …………………..................................

3. How Unusual was the Cold Winter of 2013/14 in the Upper Midwest?............................................10

4. Was the Cold Eastern Us Winter of 2014 Due to Increased Variability? .............................................15

5. The 2014 Extreme Flood on the Southeastern Canadian Prairies .................................................... 20

6. Extreme North America Winter Storm Season of 2013/14: Roles of Radiative Forcing and the Global Warming Hiatus.......................................................................................................................... 25

7. Was the Extreme Storm Season in Winter 2013/14 Over the North Atlantic and the United Kingdom Triggered by Changes in the West Pacific Warm Pool?.

8. Factors Other Than Climate Change, Main Drivers of 2014/15 Water Shortage in Southeast Brazil..

9. Causal Influence of Anthropogenic Forcings on the Argentinian Heat Wave of December 2013

10. Extreme Rainfall in the United Kingdom During Winter 2013/14: The Role of Atmospheric Circulation and Climate Change.

II. Hurricane Gonzalo and its Extratropical Transition to a Strong European Storm.............................5I

12. Extreme Fall 2014 Precipitation in the Cévennes Mountains ........................................................ 56

13. Record Annual Mean Warmth Over Europe, the Northeast Pacific, and the Northwest Atlantic During 2014: Assessment of Anthropogenic Influence.

14. The Contribution of Human-Induced Climate Change to the Drought of 2014 in the Southern

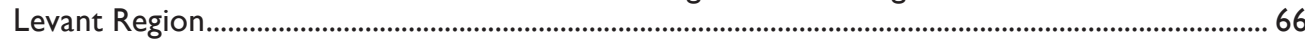

15. Drought in the Middle East and Central-Southwest Asia During Winter 2013/14............................ I

16. Assessing the Contributions of East African and West Pacific Warming to the 2014 Boreal Spring East African Drought

17. The 2014 Drought in the Horn of Africa: Attribution of Meteorological Drivers.

18. The Deadly Himalayan Snowstorm of October 2014: Synoptic Conditions and Associated Trends

19. Anthropogenic Influence on the 2014 Record-Hot Spring in Korea ................................................ 95

20. Human Contribution to the 2014 Record High Sea Surface Temperatures Over the Western Tropical And Northeast Pacific Ocean.

21. The 2014 Hot, Dry Summer in Northeast Asia .............................................................................. 105

22. Role of Anthropogenic Forcing in 2014 Hot Spring in Northern China........................................... III

23. Investigating the Influence of Anthropogenic Forcing and Natural Variability on the 2014 Hawaiian Hurricane Season.

24. Anomalous Tropical Cyclone Activity in the Western North Pacific in August 2014 .................. 120

25. The 2014 Record Dry Spell at Singapore: An Intertropical Convergence Zone (ITCZ) Drought.

26. Trends in High-Daily Precipitation Events in Jakarta and the Flooding of January 2014 ................131

27. Extreme Rainfall in Early July 2014 in Northland, New Zealand-Was There an Anthropogenic Influence?.

28. Increased Likelihood of Brisbane, Australia, G20 Heat Event Due to Anthropogenic Climate Change.

29. The Contribution of Anthropogenic Forcing to the Adelaide and Melbourne, Australia, Heat Waves of January 2014

30 Contributors to the Record High Temperatures Across Australia in Late Spring 2014 ............... 149

3I. Increased Risk of the 20I4 Australian May Heatwave Due to Anthropogenic Activity................ I54

32. Attribution of Exceptional Mean Sea Level Pressure Anomalies South of Australia in August 2014

33. The 2014 High Record of Antarctic Sea Ice Extent........................................................................ 163

34. Summary and Broader Context....................................................................................................... 168 


\section{ABSTRACT_Stephanie C. Herring, Martin P. Hoerling, James P. Kossin, Thomas C. Peterson, and Peter A. Stott}

Understanding how long-term global change affects the intensity and likelihood of extreme weather events is a frontier science challenge. This fourth edition of explaining extreme events of the previous year (2014) from a climate perspective is the most extensive yet with 33 different research groups exploring the causes of 29 different events that occurred in 2014. A number of this year's studies indicate that human-caused climate change greatly increased the likelihood and intensity for extreme heat waves in 2014 over various regions. For other types of extreme events, such as droughts, heavy rains, and winter storms, a climate change influence was found in some instances and not in others. This year's report also included many different types of extreme events. The tropical cyclones that impacted Hawaii were made more likely due to human-caused climate change. Climate change also decreased the Antarctic sea ice extent in 2014 and increased the strength and likelihood of high sea surface temperatures in both the Atlantic and Pacific Oceans. For western U.S. wildfires, no link to the individual events in 2014 could be detected, but the overall probability of western U.S. wildfires has increased due to human impacts on the climate.
Challenges that attribution assessments face include the often limited observational record and inability of models to reproduce some extreme events well. In general, when attribution assessments fail to find anthropogenic signals this alone does not prove anthropogenic climate change did not influence the event. The failure to find a human fingerprint could be due to insufficient data or poor models and not the absence of anthropogenic effects.

This year researchers also considered other humancaused drivers of extreme events beyond the usual radiative drivers. For example, flooding in the Canadian prairies was found to be more likely because of human land-use changes that affect drainage mechanisms. Similarly, the Jakarta floods may have been compounded by land-use change via urban development and associated land subsidence. These types of mechanical factors reemphasize the various pathways beyond climate change by which human activity can increase regional risk of extreme events. 


\title{
17. THE 2014 DROUGHT IN THE HORN OF AFRICA: ATTRIBUTION OF METEOROLOGICAL DRIVERS
}

\author{
T. R. Marthews, F. E. L. Otto, D. Mitchell, S. J. Dadson, and R. G. Jones
}

Ensemble modelling of the East African 2014 long rains season suggests no anthropogenic influence on the likelihood of low rainfall but clear signals in other drivers of drought.

Introduction. Drought has always been a natural part of climatic variability in Africa (Masih et al. 2014), but the Greater Horn of Africa region (GHoA; taken as the area east of the Nile River between Khartoum, Sudan, and Mombasa, Kenya, see Fig. 17.1) is especially vulnerable to the impacts of drought because of a unique combination of several adverse factors. Despite favorable soils, the GHoA has long experienced widespread poverty and high levels of food insecurity (Global Hunger Index 2013; FEWS NET 2015). Political instability and the high dependence of GHoA's population on rain-fed agriculture exacerbate the impacts of droughts (Love 2009; Masih et al. 2014).

Most areas of the GHoA experience two rainy seasons: the "long rains" during March-June as the intertropical convergence zone (ITCZ) crosses the equator from south to north and the "short rains" during October-December as the ITCZ returns to the south (Yang et al. 2015). The long rains have received much recent attention, first, because identifying their large-scale climate drivers has proved challenging (Lyon and DeWitt 2012; Funk et al. 2014; Yang et al. 2014) and second, because since 1999 the long rains have been decreasing across the region (Lyon and DeWitt 2012; Lyon 2014), with disastrous consequences for local populations (Boulter et al. 2013; Masih et al. 2014).

The focus of this study is the 2014 drought in GHoA. In late 2013, the short rains failed almost

\begin{abstract}
AFFILIATIONS: MARTHEWS-School of Geography and the Environment, University of Oxford, Oxford, United Kingdom; Отто-Environmental Change Institute, University of Oxford, Oxford, United Kingdom; MITCHELL-Environmental Change Institute, Oxford University, Oxford, United Kingdom; DADsONSchool of Geography and the Environment, University of Oxford, Oxford, United Kingdom; JONES-School of Geography and the Environment, University of Oxford, Oxford, United Kingdom and Met Office Hadley Centre, Exeter, United Kingdom
\end{abstract}

DOI:I0.II75/BAMS-D-I5-00II5.I

A supplement to this article is available online $(10.1175$ /BAMS-D-I5-001I5.2) completely in Kenya, Somalia, and southern Ethiopia, leading to an abnormally-dry growing season from January to March 2014, followed by a widespread drought in many agricultural areas of the GHoA because of much-reduced long rains during March to June (FAO 2014; ECHO 2014; see also Hoell and Funk 2014). A similar failure of both rainy seasons occurred in 2010-11, causing widespread crop failures in 2011 and led, as a result of political instability, to famine in Somalia (UNOCHA 2011; Lott et al. 2013; Coghlan et al. 2014; Nicholson 2014). Because climaterelated extremes have been the dominant trigger of natural disasters in the GHoA (Omondi et al. 2014), understanding these extreme climatic events and their impacts is critically important.

The decrease of the long rains during March to June has been the dominant driver of the increased frequency and severity of droughts in the GHoA in recent years (Yang et al. 2015), but how much of this decrease is part of natural variability and how much is attributable to anthropogenic climate change? Events such as drought usually occur as a result of a combination of factors (Trenberth 2012), only some of which may be related to recent human activities. Therefore, attribution studies of extreme climatic events are important, but such studies remain rare for Africa partly because of shorter instrumental records that limit our ability to assign causation with certainty (Tierney et al. 2013; Stott et al. 2014). The attribution issue gains added urgency because extreme weather events such as heatwaves, floods, and droughts can be associated with high levels of loss and damage to human society (James et al. 2014; Stott et al. 2014). In this study we ask whether human-induced climate change played a role in the meteorology of the 2014 East African long rains season that could have contributed to the 2014 drought in the GHoA.

Methods. We use probabilistic event attribution (PEA) techniques (e.g., Allen 2003; Stott et al. 2014), which 
involve taking an ensemble approach to the problem of estimating the response of the climate system to external forcing (Massey et al. 2015). Two sets of simulations are employed: one factual set generated from multiple realizations of the event in question using observed climate forcings and one counterfactual set based on the "world that might have been without higher greenhouse gas emissions". These counterfactual simulations are the result of running the same climate model but with anthropogenic greenhouse gas forcings removed (Otto et al. 2015). Comparisons between these two ensembles allow us to quantify the change in extreme event probability that is attributable to anthropogenic as opposed to natural drivers (Pall et al. 2011).

Large ensembles of model simulations are necessary for PEA to understand extreme or rare events (Allen 2003). Our ensemble sets are simulated using HadRM3P, a regional climate model, embedded in the Hadley Centre atmosphere-only general circulation model (HadAM3P) with perturbed initial conditions and observed sea surface temperatures (SSTs), derived from the operational sea surface temperature and sea ice analysis (OSTIA; Stark et al. 2007). These simulations were run using the volunteer computing framework weather@ home (Massey et al. 2015).

We used a $0.44^{\circ}$ resolution simulation domain ( $\sim 50 \mathrm{~km}$ at midlatitudes) covering Africa from $14.3^{\circ} \mathrm{S}$ to $46.0^{\circ} \mathrm{N}$ and from $25.0^{\circ} \mathrm{W}$ to $62.6^{\circ} \mathrm{E}$ : a much greater area than the GHoA (Fig. 17.1) to ensure that edge effects were negligible during these simulations. Data from factual and counterfactual simulations form the basis of the subsequent analysis. Statistics are calculated for an area comprising south Ethiopia, north Kenya, and south-west Somalia, the areas where precipitation deficit, hydrological drought, and food insecurity overlapped during the 2014 Horn of Africa drought event (FAO 2014; hereafter the "center of drought impact", CDI; Fig. 17.1).
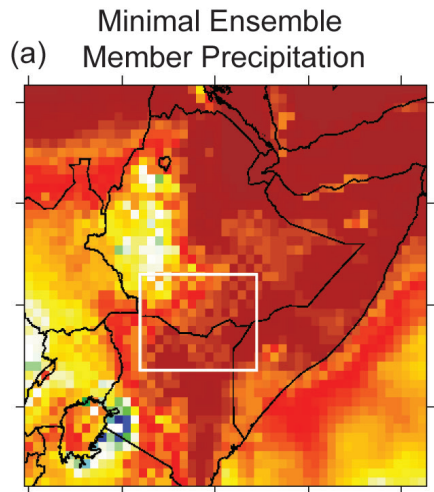

(c) TAMSAT Precipitation

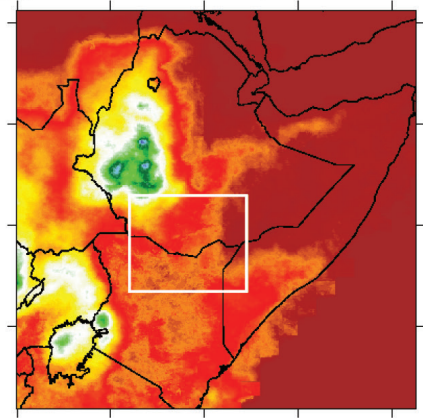

Maximal Ensemble

(b) Member Precipitation

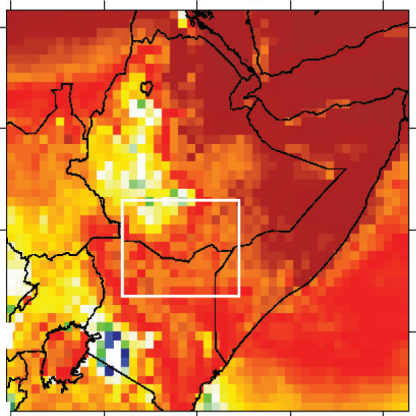

(d) TRMM Precipitation

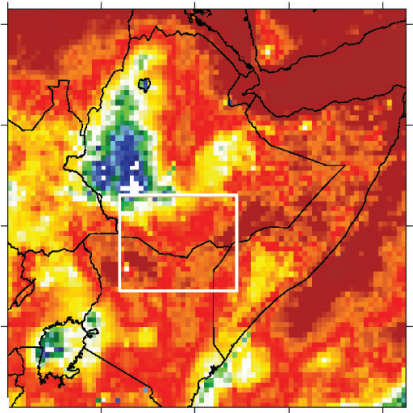

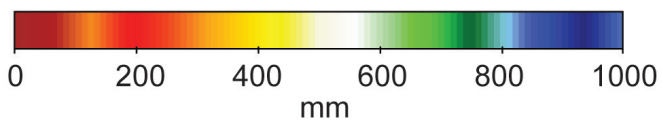

(e) Mean Ensemble Member Minus TAMSAT

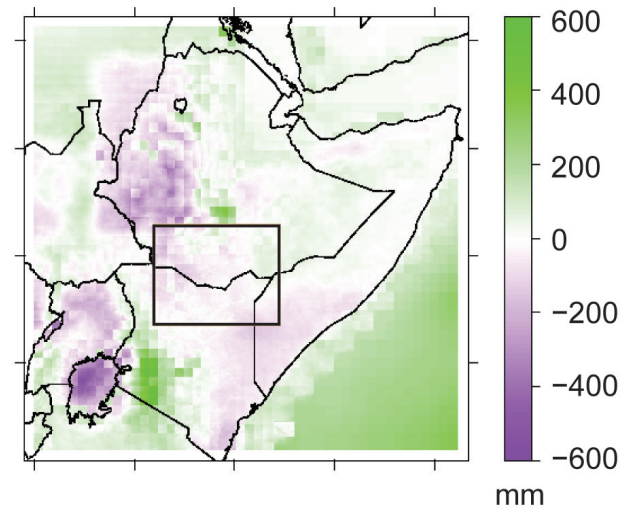

FIG. I7.I. Long rains (Mar-Jun) total precipitation ( $\mathrm{mm}$ ) for 2014 as simulated from the weather@home factual experiment, showing the two ensemble members that presented the (a) driest and (b) wettest seasonal means over the CDI. For comparison, estimates of the observed precipitation for the same season are shown from (c) the TAMSAT (e.g., Tarnavsky et al. 20I4; n.b. Yemen and oceanic points are not included in TAMSAT) and (d) TRMM datasets (e.g., Dinku et al. 2007) and (e) the anomaly between the mean factual ensemble and TAMSAT (green shows areas where the model overestimates precipitation, purple underestimations). The CDI during 2014 is boxed [Lake Turkana, Kenya $\left(36.00^{\circ} \mathrm{E}\right)$, to the Juba River, Somalia $\left(42.28^{\circ} \mathrm{E}\right)$, and from Wajir, Kenya $\left(1.75^{\circ} \mathrm{N}\right)$, to Imi, Ethiopia $\left.\left(6.46^{\circ} \mathrm{N}\right)\right]$, coinciding approximately with the Turkana Basin/Southeastern Horn region of Liebmann et al. (20I4). 
Results. With the focus of our study on simulations of the 2014 East African long rains season (Fig. 17.1), we compared the weather@ home simulations of the seasonal average rainfall in representative members of the factual ensemble with two estimates of the observed rainfall. Initially we examined the distribution of simulated average March to June precipitation over the CDI (Fig. 17.1) and divided this into 20 bins, from each of which an equal number of representative members was chosen (20 bins was an optimal number in order to allow adequate sampling of the tail of low-precipitation simulations). The general spatial pattern of observed rainfall estimates for the 2014 March to June season is correctly returned by the model simulations (Fig. 17.1). Specifically, the spatial mean long rains total precipitation for the CDI averaged across the ensemble was $155 \mathrm{~mm}$ (ranging from $94 \mathrm{~mm}$ to $195 \mathrm{~mm}$ for the minimal and maximal ensembles shown in Fig. 17.1) compared with TAMSAT (e.g., Tarnavsky et al. 2014) and TRMM (e.g., Dinku et al. 2007) data averages for 2014 of $169 \mathrm{~mm}$ and 201 $\mathrm{mm}$, respectively. In relation to available data, 2014 was in the driest $33 \%$ of years recorded since 1983 (TAMSAT data, Supplemental Fig. S17.1) and its importance as an extreme drought event is not in question.

We focus on surface (1.5-m) meteorological variables that are relevant to the vegetation and soil moisture state of the land surface and therefore to indicators of drought. These are precipitation, which directly influences soil moisture, along with temperature, downward shortwave and longwave radiation, (b)

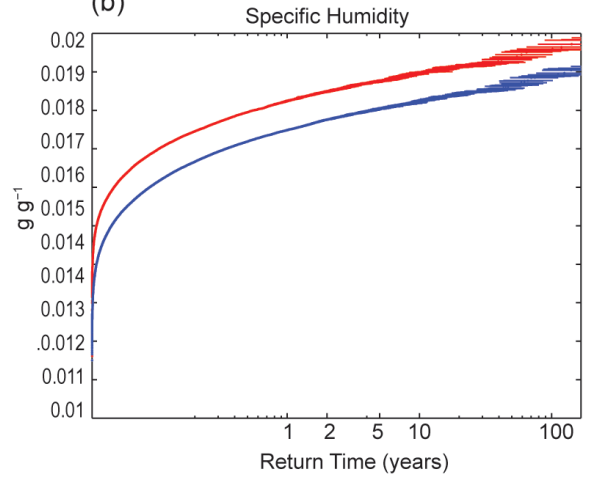

(d)

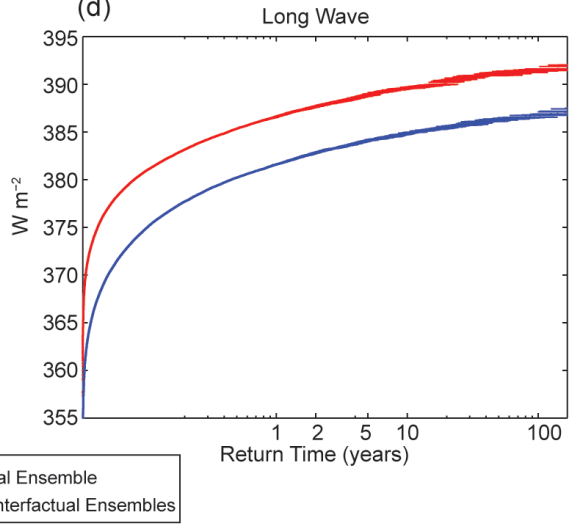

(e)

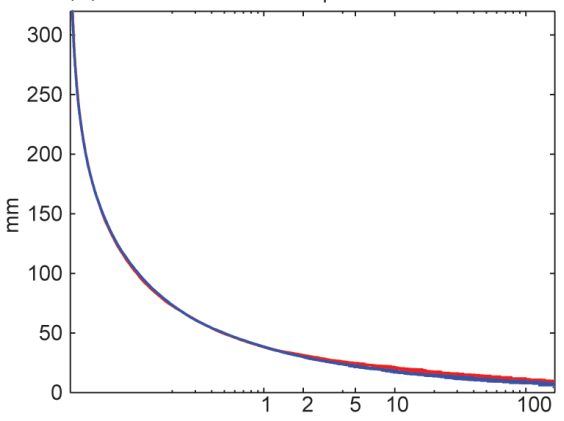

Fig. 17.2. Return-time periods (years) from the regional model (HadRM3P) showing the change in occurrence frequency between simulations of the factual (red) and counterfactual (blue) ensembles for extreme values of a selection of climate model outputs (a) surface temperature (K), (b) specific humidity ( $g$ $\left.\mathrm{g}^{-1}\right),(c)$ downward shortwave radiation received at the surface $\left(\mathrm{W} \mathrm{m}^{-2}\right)$, (d) downward longwave radiation $\left(\mathrm{W} \mathrm{m}^{-2}\right)$ and (e) total precipitation $(\mathrm{mm})$. Means and $5 \%-95 \%$ confidence intervals are calculated from bootstrapping for each threshold value across all ensembles in the set (for details see Otto et al. 2015).

and specific humidity, which in turn affect potential evapotranspiration and other variables relevant to vegetation productivity. In Fig. 17.2 we compare simulations of these variables in the factual climate with the corresponding counterfactual simulations averaged over the CDI. These results show clear increases in the occurrence frequency of higher temperature and humidity at the surface (Figs. 17.2a,b), along with a slightly lower shortwave input but a higher longwave flux at the surface (Figs. 17.2c,d). These differences 
are attributable to human-induced changes in greenhouse gas concentrations. Nonetheless, there is no corresponding change in precipitation (Fig. 17.2e).

Discussion. As large-scale teleconnections play a significant role in the climate of the GHoA, for example, robust correlations have been found linking the East African long rains with SST oscillations such as the Indian Ocean dipole and the El Niño southern oscillation (ENSO; e.g., Funk et al. 2014; Lanckriet et al. 2014; Lyon 2014; Liebmann et al. 2014; Yang et al. 2014, 2015), it is important to note that both our factual and counterfactual simulation ensembles use SSTs with essentially the same oscillations and hence the same large-scale teleconnections. With the SSTs used in the counterfactual simulation being formed from observed values with estimated large-scale anthropogenic SST signals subtracted, the SST gradients, and their temporal evolution, are very similar to the observed values. Thus the same teleconnection signature will be present in both sets of simulations and by comparing these we are able to assess the additional effect of the anthropogenic influences (Otto et al. 2015).

Our results suggest that while anthropogenic increases in greenhouse gas concentrations and associated warming of sea surface temperatures did not increase the likelihood of reduced precipitation in the 2014 East African long rains season, human influences did result in higher temperatures and increased net incoming radiation at the surface over the region most affected by the drought. Conversely, Lott et al. (2013) did find that the failure of the 2011 long rains was more probable following anthropogenic climate change, indicating that climatic conditions for the 2014 drought were not identical to the 2011 drought in the same area. The drivers of the East African long rains are not yet sufficiently understood (Nicholson 2014; Yang et al. 2014, 2015) so there are many possible reasons why anthropogenic change was less significant in terms of climatological drought in 2014 than 2011: for example, 2014 was globally a warmer year than 2011 which perhaps overwhelmed a relatively small anthropogenic signal.

These findings do not constitute a clear attribution of the 2014 climatological drought to human influences. However, simulating the causal chain from precipitation deficit to hydrological or agricultural drought and other impacts is nontrivial and involves many processes that are themselves poorly known at high resolution (Prudhomme et al. 2014). Increased temperature and net incoming radiation at the surface both enhance evaporation and, therefore, the conditions for either or both hydrological or agricultural drought so we suggest that the occurrence of climatological drought and drought impacts may be decoupled in this region. Our results show that anthropogenic influence could well have contributed to drought conditions during the East African long rains but also that more comprehensive studies are required before more definitive statements can be made.

ACKNOWLEDGMENTS. This work was conducted as part of the ACE-Africa project, University of Oxford (www.eci.ox.ac.uk/research/climate /ACEAfrica.php). We would like to thank the Met Office Hadley Centre PRECIS team and our colleagues at the Oxford eResearch Centre for their technical and scientific support for the development and application of Weather@Home. Finally, we would like to thank all of the volunteers who have donated their computing time to Weather@Home.

\section{REFERENCES}

Allen, M., 2003: Liability for climate change. Nature, 421, 891-892.

Boulter, S., J. Palutikof, D. J. Karoly, and D. Guitart, 2013: Natural Disasters and Adaptation to Climate Change. Cambridge University Press, 273 pp.

Coghlan, C., M. Muzammil, J. Ingram, J. Vervoort, F. Otto, and R. James, 2014: A sign of things to come? Examining four major climate-related disasters, 2010-2013, and their impacts on food security. Oxfam Res. Rep., Oxfam International, 43 pp. [Available online at http://go.oxfam.ca/docs/sign-of -things-to-come-2014-09.pdf.]

Dinku, T., P. Ceccato, E. Grover-Kopec, M. Lemma, S. J. Connor, and C. F. Ropelewski, 2007: Validation of satellite rainfall products over East Africa's complex topography. Int. J. Remote Sens., 28, 1503-1526.

ECHO, 2014:Humanitarian implementation plan(HIP), 2015: Horn of Africa. ECHO/-HF/BUD/2015/91000, European Commission Humanitarian Aid Department, 17 pp. [Available online at http:// reliefweb.int/sites/reliefweb.int/files/resources /hoa_en_4.pdf.]

FEWS NET, 2015: East Africa. Famine Early Warning Systems Network, accessed 9 June 2015. [Available online at www.fews.net/east-africa/.] 
FAO, 2014: Greater Horn of Africa: Late and erratic rains raise serious concern for crop and livestock production. GIEWS update, Food and Agricultural Organization, accessed 9 June 2015. [Available online at www.fao.org/giews/english/shortnews /hof03062014.pdf.]

Funk, C., A. Hoell, S. Shukla, I. Bladé, B. Liebmann, J. B. Roberts, F. R. Robertson, and G. Husak, 2014: Predicting East African spring droughts using Pacific and Indian Ocean sea surface temperature indices. Hydrol. Earth Syst. Sci., 18, 4965-4978, doi:10.5194 /hess-18-4965-2014.

Global Hunger Index, 2013: GHI map. Accessed 9 June 2015. [Available online at www.ifpri.org/tools /2013-ghi-map.]

Hoell, A., and C. Funk, 2014: Indo-Pacific sea surface temperature influences on failed consecutive rainy seasons over eastern Africa. Climate Dyn. 43, 16451660, doi:10.1007/s00382-013-1991-6.

James, R., F. Otto, H. Parker, E. Boyd, R. Cornforth, D. Mitchell, and M. Allen, 2014: Characterizing loss and damage from climate change. Nat. Climate Change, 4, 938-939, doi:10.1038/nclimate2411; Correction (2015), 5, 92, doi:10.1038/nclimate2499.

Lanckriet, S., A. Frankl, E. Adgo, P. Termonia, and J. Nyssen, 2014: Droughts related to quasi-global oscillations: a diagnostic teleconnection analysis in North Ethiopia. Int. J. Climatol., 35, 1534-1542, doi:10.1002/joc.4074.

Liebmann, B., and Coauthors, 2014: Understanding recent eastern Horn of Africa rainfall variability and change. J. Climate, 27, 8630-8645, doi:10.1175 /JCLI-D-13-00714.1.

Lott, F. C., N. Christidis, and P. A. Stott, 2013: Can the 2011 East African drought be attributed to humaninduced climate change? Geophys. Res. Lett., 40, 1177-1181, doi:10.1002/grl.50235.

Love, R., 2009: Economic drivers of conflict and cooperation in the Horn of Africa. ARP BP 2009/01, Chatham House, 16 pp. [Available online at www .chathamhouse.org/publications/papers/view /109208.]

Lyon, B., 2014: Seasonal drought in the Greater Horn of Africa and its recent increase during the MarchMay long rains. J. Climate, 27, 7953-7975, doi:10.1175 /JCLI-D-13-00459.1.

— , and D. G. DeWitt, 2012: A recent and abrupt decline in the East African long rains. Geophys. Res. Lett., 39, L02702, doi:10.1029/2011GL050337.
Masih, I., S. Maskey, F. E. F. Mussá, and P. Trambauer, 2014: A review of droughts on the African continent: A geospatial and long-term perspective. Hydrol. Earth Syst. Sci., 18, 3635-3649, doi:10.5194/hess-18 -3635-2014.

Massey, N., and Coauthors, 2015: weather@home-development and validation of a very large ensemble modelling system for probabilistic event attribution. Quart. J. Roy. Meteor. Soc.,141, 1528-1545, doi:10.1002/qj.2455.

Nicholson, S. E., 2014: A detailed look at the recent drought situation in the Greater Horn of Africa. J. Arid Environ., 103, 71-79, doi:10.1016 /j.jaridenv.2013.12.003.

Omondi, P. A., and Coauthors, 2014: Changes in temperature and precipitation extremes over the Greater Horn of Africa region from 1961 to 2010. Int. J. Climatol., 34, 1262-1277, doi:10.1002/joc.3763.

Otto, F. E. L., E. Boyd, R. G. Jones, R. J. Cornforth, R. James, H. R. , Parker, and M. R. Allen, 2015: Attribution of extreme weather events in Africa: a preliminary exploration of the science and policy implications. Climatic Change, doi:10.1007/s10584 -015-1432-0, Open Access.

Pall, P., T. Aina, D. A. Stone, P. A. Stott, T. Nozawa, A. G. J. Hilberts, D. Lohmann, and M. R. Allen, 2011: Anthropogenic greenhouse gas contribution to flood risk in England and Wales in autumn 2000. Nature, 470, 382-385.

Prudhomme, C., and Coauthors, 2014: Hydrological droughts in the 21st century, hotspots and uncertainties from a global multimodel ensemble experiment. Proc. Natl. Acad. Sci. USA, 111, 3262-3267, doi:10.1073/pnas.1222473110.

Stark, J. D., C. J. Donlon, M. J. Martin, and M. E. McCulloch, 2007: OSTIA: An operational, high resolution, real time, global sea surface temperature analysis system. Proc. IEEE Oceans 2007 Europe Int. Conf., Aberdeen, UK, Institute of Electrical and Electronics Engineers, 331-334.

Stott, P. A., G. C. Hegerl, S. C. Herring, M. P. Hoerling, T. C. Peterson, X. Zhang, and F. W. Zwiers, 2014: Introduction to explaining extreme events of 2013 from a climate perspective. Bull. Amer. Meteor. Soc., 95 (9), S1-S3.

Tarnavsky, E., D. Grimes, R. Maidment, E. Black, R. P. Allan, and M. Stringer, 2014: Extension of the TAMSAT Satellite-Based Rainfall Monitoring over Africa and from 1983 to Present. J. Appl. Meteor. Climatol., 53, 2805-2822, doi:10.1175/JAMC-D-14-0016.1. 
Tierney, J. E., J. E. Smerdon, K. J. Anchukaitis, and R. Seager, 2013: Multidecadal variability in East African hydroclimate controlled by the Indian Ocean. Nature, 493, 389-392, doi:10.1038/nature11785.

Trenberth, K. E., 2012: Framing the way to relate climate extremes to climate change. Climatic Change, 115, 283-290, doi:10.1007/s10584-012-0441-5.

UNOCHA, 2011: Eastern Africa drought. Humanitarian Rep. 4, UN Office for the Coordination of Humanitarian Affairs, $10 \mathrm{pp}$. [Available online at http:// reliefweb.int/sites/reliefweb.int/files/resources /Full_Report_1717.pdf.]

Yang, W., R. Seager, M. A. Cane, and B. Lyon, 2014: The East African long rains in observations and models. J. Climate, 27, 7185-7202, doi:10.1175 /JCLI-D-13-00447.1.

— - - — , and — 2015: The annual cycle of East African precipitation. J. Climate, 28, 23852404, doi:10.1175/JCLI-D-14-00484.1. 


\begin{tabular}{|c|c|c|c|}
\hline \multicolumn{4}{|c|}{ ON EVENT STRENGTH † } \\
\hline & INCREASE & DECREASE & NOT FOUND OR UNCERTAIN \\
\hline Heat & $\begin{array}{l}\text { Australia (Ch. 31) } \\
\text { Europe (Ch.13) } \\
\text { S. Korea (Ch. 19) }\end{array}$ & & $\begin{array}{l}\text { Australia, Adelaide \& Melbourne } \\
\text { (Ch. 29) } \\
\text { Australia, Brisbane (Ch.28) }\end{array}$ \\
\hline Cold & & Upper Midwest (Ch.3) & \\
\hline $\begin{array}{l}\text { Winter } \\
\text { Storms and } \\
\text { Snow }\end{array}$ & & & $\begin{array}{l}\text { Eastern U.S. (Ch. 4) } \\
\text { N. America (Ch. 6) } \\
\text { N. Atlantic (Ch. 7) }\end{array}$ \\
\hline $\begin{array}{l}\text { Heavy } \\
\text { Precipitation }\end{array}$ & Canada** (Ch. 5) & & $\begin{array}{l}\text { Jakarta**** (Ch. 26) } \\
\text { United Kingdom } * * *(C h .10) \\
\text { New Zealand (Ch. 27) }\end{array}$ \\
\hline Drought & $\begin{array}{l}\text { E. Africa (Ch. 16) } \\
\text { E. Africa* (Ch. 17) } \\
\text { S. Levant (Ch. 14) }\end{array}$ & & $\begin{array}{l}\text { Middle East and S.W. Asia } \\
\text { (Ch. I5) } \\
\text { N.E. Asia (Ch. 2I) } \\
\text { Singapore (Ch. 25) }\end{array}$ \\
\hline $\begin{array}{l}\text { Tropical } \\
\text { Cyclones }\end{array}$ & & & $\begin{array}{l}\text { Gonzalo (Ch. II) } \\
\text { W. Pacific (Ch. 24) }\end{array}$ \\
\hline Wildfires & & & California (Ch. 2) \\
\hline $\begin{array}{l}\text { Sea Surface } \\
\text { Temperature }\end{array}$ & $\begin{array}{l}\text { W. Tropical \& N.E. Pacific (Ch. 20) } \\
\text { N.W. Atlantic \& N.E. Pacific (Ch. I3) }\end{array}$ & & \\
\hline $\begin{array}{l}\text { Sea Level } \\
\text { Pressure }\end{array}$ & S. Australia (Ch. 32) & & \\
\hline $\begin{array}{l}\text { Sea Ice } \\
\text { Extent }\end{array}$ & & & Antarctica (Ch. 33) \\
\hline
\end{tabular}

$\dagger$ Papers that did not investigate strength are not listed.

t† Papers that did not investigate likelihood are not listed.

* No influence on the likelihood of low rainfall, but human influences did result in higher temperatures and increased net incoming radiation at the surface over the region most affected by the drought.

** An increase in spring rainfall as well as extensive artificial pond drainage increased the risk of more frequent severe floods from the enhanced rainfall.

*** Evidence for human influence was found for greater risk of UK extreme rainfall during winter 2013/14 with time scales of 10 days

***** The study of Jakarta rainfall event of 2014 found a statistically significant increase in the probability of such rains over the last 115 years, though the study did not establish a cause. 


\title{
ON EVENT LIKELIHOOD ††
}

Argentina (Ch. 9)

Australia (Ch. 30, Ch. 3I)

Australia, Adelaide (Ch. 29)

Australia, Brisbane (Ch. 28)

Melbourne, Australia (Ch. 29)

Europe (Ch. 13)

S. Korea (Ch. 19)

China (Ch. 22)

Cold
Winter
Storms and
Snow

Heavy
Precipitation

(a)

N. America (Ch. 6)

S. France (Ch. I2)

Middle East and S.W. Asia (Ch. 15)

Drought

E. Africa (Ch. 16)

S. Levant (Ch. 14)

E. Africa* (Ch. 17)

N.E. Asia (Ch. 2I)

Wildfires

\author{
California (Ch. 2)
}

\section{W. Tropical \& N.E. Pacific}

Sea Surface

Temperature

(Ch. 20)

N.W. Atlantic \& N.E. Pacific (Ch. 13)

Sea Level

Pressure

S. Australia (Ch. 32)

Sea Ice

Extent

w.

Antarctica (Ch. 33)

† Papers that did not investigate strength are not listed.

t† Papers that did not investigate likelihood are not listed.

* No influence on the likelihood of low rainfall, but human influences did result in higher temperatures and increased net incoming radiation at the surface over the region most affected by the drought.

** An increase in spring rainfall as well as extensive artificial pond drainage increased the risk of more frequent severe floods from the enhanced rainfall.

*** Evidence for human influence was found for greater risk of UK extreme rainfall during winter 2013/14 with time scales of 10 days

***** The study of Jakarta rainfall event of 2014 found a statistically significant increase in the probability of such rains over the last II5 years, though the study did not establish a cause. 